\title{
Contraposições entre estética e ensino da arte: \\ o caso de "A triste história de Eredegalda"
}

\author{
Karla Raphaella Costa Pereiraid \\ Centro Universitário Uninassau, Fortaleza, CE, Brasil \\ Frederico Jorge Ferreira Costaiic \\ Universidade Estadual do Ceará, Fortaleza, CE, Brasil \\ Ana Paula Sancho Diogo \\ Prefeitura Municipal de Fortaleza, Fortaleza, CE, Brasil
}

\begin{abstract}
Resumo
Este artigo resulta da análise do romance "A triste história de Eredegalda", do livro Enquanto o sono não vem, de José Mauro Brant. Em 2017, esse livro foi retirado das escolas públicas brasileiras por tematizar o incesto. A polêmica ensejou debates de base moral, estética e pedagógica. O estudo é uma análise literária, o qual foi realizado com fundamento na estética de György Lukács e teve como objetivo superar a dualidade moralismo - liberdade artística no interior desse debate, apontando uma necessidade anterior: julgar acerca do possível papel pedagógico de "A triste história de Eredegalda". Essa situação concreta possibilitou avançar no exame do caráter educativo das obras de arte e no uso da literatura como instrumento pedagógico. Apresenta-se a situação geral, depois expõem-se os fundamentos sob os quais a investigação se fundou e, por último, revela-se o ponto de vista dos autores sobre a obra em questão, em caráter de ensaio.
\end{abstract}

Palavras-chave

Ensino da arte. Ensino de literatura. Marxismo.

\section{Contrapositions between aesthetics and art teaching: the case of}

\section{"Eredegalda's sad story"}

\begin{abstract}
This article results from the analysis of the novel Eredegalda's sad story from the book While sleep does not come, by José Mauro Brant. In 2017, this book was forbidden in the Brazilian public schools for focusing on incest. The controversy gave rise to moral, aesthetic and pedagogical debates. The study is a literary analysis, it was carried out based on the aesthetics of György Lukács and aimed to overcome the duality of moralism-artistic freedom within this debate, pointing out an earlier need: to reflect on the possible pedagogical role of "Eredegalda's sad story". This concrete situation made it possible to move forward in examining the educational character of works of art and the use of literature as a pedagogical instrument. It presents the general situation, then
\end{abstract}


explains the fundamentals on which the investigation was based and, finally, reveals the author's point of view on the work in question.

\author{
Keywords \\ Teaching of art. Teaching of literature. Marxism.
}

\title{
Contraposiciones entre estética y enseñanza del arte: \\ el caso de "La triste historia de Eredegalda"
}

\begin{abstract}
Resumen sobre la obra en cuestión, en carácter de ensayo.

Palabras clave

Enseñanza de arte. Enseñanza de Literatura. Marxismo.
\end{abstract}

Este artículo resulta del análisis de "La triste historia de Eredegalda", del libro Mientras el sueño no viene, de José Mauro Brant. En el año 2017, ese libro fue retirado de las escuelas públicas brasileñas por tematizar el incesto. La polémica planteó debates de base moral, estética y pedagógica. El estudio es un análisis literario. Fue realizado según la estética de György Lukács y tuvo como objetivo superar la dualidad moralismo - libertad artística en el interior de ese debate, apuntando a una necesidad anterior: juzgar acerca del posible papel pedagógico de "La triste historia de Eredegalda". Esta situación concreta posibilitó avanzar en el examen del carácter educativo de las obras de arte y en el uso de la literatura como instrumento pedagógico. Se presenta la situación general, después se exponen los fundamentos bajo los cuales la investigación se fundó y, por último, se revela el punto de vista de los autores

\section{Introdução}

\begin{abstract}
A literatura não se faz para ensinar: é a reflexão sobre a literatura que nos ensina. (JACINTO DO PRADO COELHO).
\end{abstract}

Este artigo expõe os resultados da análise do romance ${ }^{1}$ "A triste história de Eredegalda", da editora Rocco, publicado no livro Enquanto o sono não vem, de autoria de José Mauro Brant, através do selo Jovens Leitores, em 2013. A análise foi realizada em grupo de estudo sobre a estética de György Lukács (1885-1971), filósofo marxista húngaro que se dedicou, nas últimas décadas de sua vida, a refundar as bases ontológicas do marxismo. Vinculado à pós-graduação em educação, o grupo objetiva

1 O romance tradicional é uma composição poético-musical composta por uma série de versos em redondilha maior com rima assonante. De origem medieval, foi bastante cultivado no Renascimento. Recolhidos nos Cancioneiros, foi transmitido pela tradição oral até os dias de hoje.

Educação \& Formação, Fortaleza, v. 5, n. 3, e2996, set./dez. 2020

DOI: https://doi.org/10.25053/redufor.v5i15set/dez.2996

https://revistas.uece.br/index.php/redufor/index 
apontar as contribuições da estética lukacsiana para a educação, ensino da arte e formação de professores.

"A triste história de Eredegalda" é um reconto de autoria do próprio Brant que se baseia em contos populares. A obra de Brant protagonizou polêmica de repercussão nacional ao ser denunciada por professores do ensino fundamental de Vitória, Espírito Santo (ES), devido à tematização do incesto. O livro foi distribuído pelo Ministério da Educação (MEC) como obra selecionada pelo Pacto Nacional de Alfabetização na Idade Certa (Pnaic/2014), portanto tinha passado pela análise do Centro de Alfabetização, Leitura e Escrita, vinculado à Faculdade de Educação da Universidade Federal de Minas Gerais (Ceale - FaE/UFMG).

Professores entrevistados em Vitória (ES) chegaram a afirmar que o romance poderia afastar as crianças da leitura, tendo em vista o tema apresentado a elas, que, em alfabetização, deveriam ler contos de fadas (ALBUQUERQUE, 2017b). Vale destacar que o titular da Delegacia de Proteção à Criança e ao Adolescente (DPCA/ES) condenou a obra por considerar que muitas crianças teriam vivido experiências de violência similares às da história e que as reviver poderia causar um trauma.

A prefeitura de Vitória (ES), seguida pela de Serra e de Cariacica, encaminhou o livro ao MEC para parecer pedagógico. O Ceale - FaE/UFMG elaborou parecer em favor da obra - trechos desse texto serão expostos e analisados neste artigo. Após esse parecer, o MEC resolveu recolher os 93 mil exemplares que haviam sido distribuídos em todo o Brasil. A reação do autor foi imediata: numa reportagem, alegou falta de capacitação dos professores para realizar o trabalho (ALBUQUERQUE, 2017a); noutra, apontou para uma crise moral (FERREIRA, 2017). Segundo Brant, em entrevista cedida a Ferreira (2017, s.p.):

\begin{abstract}
Eu não inventei essa história. É um livro de histórias contadas no Brasil e como todo conteúdo de cultura popular toca em assuntos delicados. As pessoas têm pouca informação sobre o que é o conto de fadas. De Chapeuzinho Vermelho a outros contos não são temas banais. É sempre uma mensagem de opressão, do bem contra o mal - afirmou Brant. - Esse livro tem 20 anos. O conto sempre gerou discussões interessantes, mas hoje em dia as pessoas são muito polarizadas. Em um momento tão difícil, com tanta coisa grave para discutir, demonizar um conto é curioso, é uma consequência de nossa crise moral.
\end{abstract}

O julgamento exposto neste artigo não se fundamenta em juízo moral nem na liberdade universal do escritor. Essas duas posições antagônicas polarizaram o debate 
acerca do romance em questão. Não se objetiva tampouco afirmar se "A triste história de Eredegalda" e os demais romances de Enquanto o sono não vem são obras literárias boas ou ruins nem se são ou não alta literatura. O que interessa aqui é o papel pedagógico dessa obra; o que cabe a estas linhas subsequentes é saber qual contribuição ela pode ou não dar à formação de indivíduos da classe trabalhadora.

Nesse sentido, este estudo faz uma análise literária, expõe um estudo bibliográfico da obra estética de Lukács e tem por resultado o ensaio literário ora manifestado. O texto apresenta inicialmente os contornos da polêmica de "A triste história de Eredegalda", aprofundando as informações dadas nesta introdução. Em seguida, põe em evidência os fundamentos teóricos sob os quais faz a análise para, por último, esboçar um ensaio sobre a função pedagógica e a função estética de uma obra de arte e como o caso de "A triste história de Eredegalda" contribui para a formação do professor de artes e literatura na escola pública brasileira.

\section{Os contornos da polêmica de "A triste história de Eredegalda"}

O romance "A triste história de Eredegalda" compõe uma antologia de recontos ${ }^{2}$ de diferentes gêneros da tradição oral popular reunidos na obra Enquanto o sono não vem, do autor José Mauro Brant (2013). Essa obra faz parte de uma coletânea de nove livros de contos que teve sua primeira publicação no ano de 2003 pela editora Rocco, através do selo Rocco Jovens Leitores. Brant estudou Letras na Pontifícia Universidade Católica do Rio de Janeiro (PUC) e hoje é ator, cantor, contador de histórias e diretor musical. Este artigo analisa apenas o reconto de "A triste história de Eredegalda", devido a sua repercussão negativa.

No trecho adiante, o autor explica o contexto de suas narrativas para que o leitor compreenda a raiz cultural dos contos populares em que se baseou para criar os seus recontos:

O romance é uma forma de poesia popular cantada que, em versos, sempre conta uma história. Num tempo em que a escrita era para muito poucos, a música escrevia na memória dos trovadores e menestréis os feitos heroicos e as

2 O reconto, diferentemente do registro da tradição oral que tem por função documentar por escrito, é um registro que sofre uma intervenção, alteração criativa por parte de um autor, mantendo as características básicas do original (CEALE, 2017). 
histórias trágicas de reinos imaginários. Muitas vezes tiveram origens em fatos reais, cantadores, que eram os repórteres da época, levavam as histórias para as praças e salões da Europa medieval. Os romances foram trazidos pelos colonizadores portugueses e espanhóis e até hoje sobrevivem na memória das velhas romanceiras nordestinas. A história da princesa assediada pelo próprio pai aparece em vários lugares do Brasil com nomes diferentes: 'Silvaninha', 'Valdomira', 'Faustina'. A versão aqui incluída foi inspirada em uma recolhida em Barbacena, Minas Gerais, e foi acrescida dos versos de um acalanto denominado 'Lá vem vindo um anjo'. (BRANT, 2013, p. 48-49).

A narrativa tem feito parte da cultura tradicional oral de gerações de brasileiros, crianças e adultos, e tem ecoado nas vozes artísticas, não apenas dos romanceiros, mas também de jovens contadores e escritores, como é o caso do autor que assina a obra Enquanto o sono não vem.

O livro, que até então passava despercebido nas prateleiras das livrarias de todo 0 Brasil, pela mídia, ganhou repercussão nacional graças ao conteúdo do romance "A triste história de Eredegalda", enquanto os demais recontos que completam a obra parecem nem existir em seu conteúdo e forma, tais como: "A história do surrão"; "As nove filhas"; "O rei cego e a cidade dos Olhos D’água"; "A linguagem dos pássaros"; "João Jiló e dois acalantos", "Consolo", que inicia a obra, e "Adeus, adeus", que a encerra. "A triste história de Eredegalda" é uma narrativa construída em dezesseis estrofes de quatro versos cada, ocupa quatro páginas do livro Enquanto o sono não vem e o conteúdo que chamou a atenção dos críticos do romance, como dito anteriormente, é a tematização do incesto.

O enredo inicia com a exaltação da beleza de três filhas de um rei, sendo uma de beleza inigualável, Eredegalda. Desejando apossar-se da beleza da filha, o pai a propõe casamento em detrimento de tornar sua mãe uma criada. A jovem Eredegalda recusa com ímpeto o desejo do pai e é castigada por isso. A mãe e as duas irmãs têm conhecimento das investidas do rei, mas não ousam contrariá-lo e negam à Eredegalda qualquer ajuda para que ela escape do castigo de comer carne salgada sem direito a água, presa numa torre.

\footnotetext{
Eram três filhas de um rei.

Todas três eram belas.

A mais bela de todas

Eredegalda se chamava

Um dia seu pai lhe disse:

- Se quiseres casar comigo,

Serás a minha esposa,

E tua mãe, nossa criada.
}

Educação \& Formação, Fortaleza, v. 5, n. 3, e2996, set./dez. 2020 


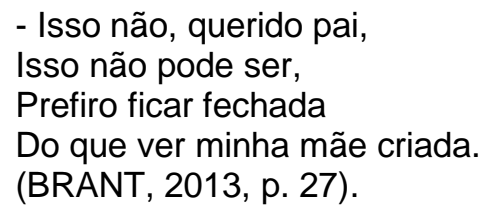

Após implorar clemência e água à mãe e às irmãs, diante da negação, a princesa recorre ao pai, que está triste por sua recusa, e promete dar-Ihe sua mão. Em resposta, o rei manda três cavaleiros à torre, jurando que o primeiro a chegar ao topo com um jarro d'água poderia casar-se com Eredegalda. Finalmente, quando os três cavaleiros chegam à torre, encontram Eredegalda morta, mas acompanhada por quatro anjos e Jesus.

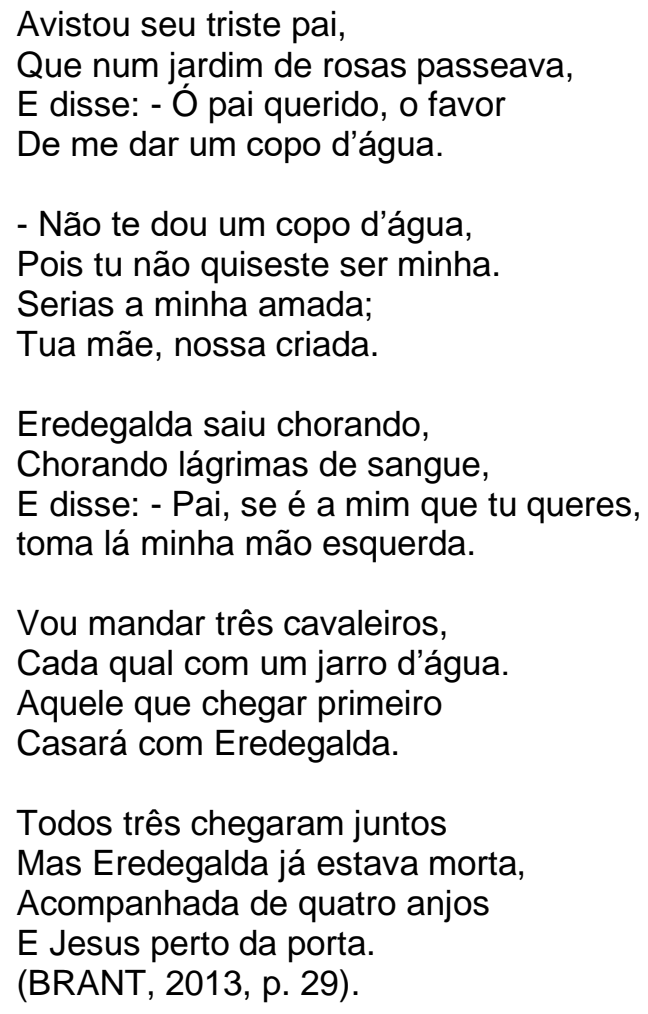

Há um desejo por parte do pai e uma recusa inicial sobre esse desejo pela filha que morre imaculada. $\mathrm{O}$ ato de incesto, motivo de toda a oposição à presença da obra em escolas públicas brasileiras, não se confirma porque a vítima se recusa, portanto trata-se de uma narrativa que tematiza e condena o incesto ao apresentar a tragédia e o sacrifício de Eredegalda.

O livro de Brant (2013) foi selecionado pelo Ceale - FaE/UFMG para compor o acervo do Pnaic (2014) do MEC. Foram distribuídos 93 mil exemplares da obra para todas 
as escolas públicas do Brasil. O livro é direcionado às crianças de 6 a 8 anos de idade dos anos iniciais do ensino fundamental, portanto em processo de alfabetização. Com essa proporção de alcance nacional, o livro entrou no cerne da discussão literária infantil.

Devido às manifestações contra a obra de Brant e após o parecer técnico emitido pela Secretaria de Educação Básica (SEB), o MEC decidiu recolher de todas as escolas públicas brasileiras os exemplares do livro Enquanto o sono não vem, considerando-o inadequado ao público ao qual se destina: crianças de 6 a 8 anos de idade. Segundo nota do MEC (2017, s.p.):

\begin{abstract}
'As crianças no ciclo de alfabetização, por serem leitores em formação e com vivências limitadas, ainda não adquiriram autonomia, maturidade e senso crítico para problematizar determinados temas com alta densidade, como é o caso da história em questão', afirma o parecer, destacando que o texto deve não somente ser adequado às competências linguísticas e textuais do estudante, mas também à sua experiência de vida e aos sentidos que a obra vai produzir no leitor.
\end{abstract}

Nota-se que o conteúdo do romance de Eredegalda foi o responsável por todo esse movimento em relação à literatura infantil escrita por Brant (2013), impondo ao Ceale - FaE/UFMG a emissão de um parecer técnico sobre o livro. Em documento, o Centro defendeu a obra Enquanto o sono não vem e afirmou que tematicamente o livro reproduz marcas linguísticas narrativas próprias dos contos populares e que o seu valor estético e qualidade editorial são adequados à formação dos leitores infantis. Vale a pena expor e, por vezes, reproduzir trechos desse parecer, pois tais apontamentos serão retomados no próximo tópico deste artigo.

Compreendeu-se, após análise, que, em seguida à apresentação da obra, o parecer do Ceale - FaE/UFMG argumenta em favor de Enquanto o sono não vem, tomando três dimensões gerais: a natureza da literatura, a relação forma e conteúdo no específico conto de Eredegalda e a relação da literatura com o mundo real figurado. Retomar-se-á aqui essas três dimensões de análise para aprofundamento e fundamentação do resultado da análise de que resulta este artigo.

Inicialmente o parecer técnico indica que, apesar de tematizar o incesto, a narrativa não faz apologia a ele, afirmando que não é o tema, mas a forma da abordagem que é considerada pelo leitor no contato com a obra. Defende ainda que temas como incesto, estupro, alcoolismo, pedofilia, violência, entre outros, estão presentes em diversas obras literárias, inclusive na Bíblia, e que a versão de Brant é 
acrescida de "[...] um acalanto, que serve, então, de reforço do enredo apresentado, destacando, como já dito mais acima, a condição angelical da personagem" (CEALE, 2017, p. 4).

\begin{abstract}
Além disso, como já apontado em sua óbvia ligação com o conto Pele de Asno, de Perrault, trata-se de um tema que há muito se faz presente na literatura infantil e não deveria causar, portanto, nenhuma surpresa a professores que trabalham com a formação de leitores infantis. O modo atemporal como se constrói a narrativa cria um distanciamento do presente e uma imersão no universo da ficção. Não se pode esquecer que as ilustrações, além do texto, levam para o universo dos contos de fada. Leitores de literatura infantil que já vivenciaram experiências de leitura com narrativas semelhantes entram nesse universo com esta condição: a de leitores de ficção. (CEALE, 2017, p. 3).
\end{abstract}

Do ponto de vista da forma e sua relação com o conteúdo, aponta que:

Ao ler especificamente 'A triste história de Eredegalda', destaca-se, já no seu início, o seguinte trecho: 'Se quiseres casar comigo, / serás minha esposa'. Nesta passagem, é importante notar, na fala do pai, a função condicional exercida pela conjunção subordinativa 'se'. A condição do 'casamento' anunciado é, entretanto, prontamente rechaçada pela filha: 'Isso não, querido pai'. Negada, portanto, a possibilidade de realização do pretenso incesto, o pai castiga a filha ('Só poderia comer carne salgada / sem beber um copo d'água'). Ao tentar amenizar seu castigo, solicitando água a seu pai, ele, novamente, reconhece a negativa ao seu desejo ('Não te dou um copo d'água, / pois tu não quiseste ser minha'). O tempo verbal utilizado, pretérito perfeito, confirma, mais uma vez, a não ocorrência do incesto, ao dar por concluída a negação acontecida no passado. Tal negativa é ainda ratificada através da indignação do pai, representada pelo verbo, agora, no futuro do pretérito: 'Serias a minha amada'. Por fim, os versos do acalanto anexados ao conto finalizam a versão livre do autor, confirmando a justa convicção de Eredegalda, então apresentada como 'um anjo', ou melhor, 'uma virgem' de véu e grinalda. Morta antes, sequer sua união aos pretendentes cavaleiros indicados pelo pai se concretiza. Temos, assim, um conto popular que tematiza, sim, o incesto, porém condenando-o, ao expor o drama e o sacrifício daquela que poderia ter sido sua vítima. (CEALE, 2017, p. 3, grifos do original).

Apropria-se ainda do conceito aristotélico de catarse para defender que, sendo

ela uma:

[...] transferência psicológica, isto é, a leitura de uma cena violenta serve para purgar o impulso de violência [...]. Ao vê-los representados no texto, o leitor os vivencia vicariamente, ou seja, por empréstimo, e assim também se liberta deles. É porque o leitor vivencia esses sentimentos negativos nos livros, nos filmes, nas telenovelas que não precisa trazê-los para a vida real. (CEALE, 2017, p. 5).

Com base no dito acima, defende que a vivência literária é ainda mais fundamental para as crianças, pois essas: 
[...] estão aprendendo a lidar com todos esses sentimentos e muitas vezes eles lhes surgem contraditórios, gerando confusão em suas cabeças. É por isso que a matéria básica da literatura infantil, desde os tempos imemoriais, é justamente composta dos medos, das angústias e das dores que implicam em crescer. (CEALE, 2017, p. 5).

Segundo o Ceale - FaE/UFMG, cenas de violência como a da estripação do lobo em Chapeuzinho Vermelho, apesar de agradáveis às crianças, não fariam delas más tratadoras de animais.

Ao contrário, cenas como essas servem para que as crianças canalizem e controlem sentimentos que são reprimidos socialmente na sua casa e na escola. Ao jogar a bruxa na panela de água fervente com Joãozinho e Maria, por exemplo, as crianças experimentam simbolicamente o sentimento de vingança. Dizendo de outra maneira, a ficção proporciona à criança um ambiente seguro onde ela pode expressar e experienciar sentimentos que nem saberia explicar. (CEALE, 2017, p. 5-6, grifo nosso).

Caminhando para sua conclusão, o parecer afirma que as cenas de violência são parte das histórias e que as crianças as compreendem assim, portanto:

[...] não são as cenas de violência presentes nessas e em outras histórias infantis que devem preocupar pais e educadores, mas sim a gratuidade delas como acontece em algumas narrativas até menos explícitas, porque isso as impede de exercer a função sublimadora que se destacou acima. (CEALE, 2017, p. 6).

O último argumento selecionado no qual o parecer compara a experiência

literária à aquisição de anticorpos no mundo natural segue abaixo:

Também não é negando ou escondendo a existência de violência no mundo que se ajuda o leitor a transformá-lo em lugar melhor para se viver. Assim como uma criança precisa brincar livremente em uma praia e caminhar na areia do parquinho até para ganhar resistência contra as bactérias e micróbios que vivem nesses ambientes, ela também precisa experimentar e conhecer, ainda que simbolicamente, os perigos e as adversidades que temperam o caráter. (CEALE, 2017, p. 6).

O parecer se encerra afirmando a indiscutível competência do Ceale FaE/UFMG na seleção rigorosa das obras que se destinam às escolas de todo o Brasil e a liberdade de que a literatura não pode prescindir. Após os destaques acima, o próximo tópico apresenta as bases teóricas e as considerações sobre a obra analisada, a crítica sofrida por ela e o consequente recolhimento de seus exemplares do território nacional. O pequeno afastamento histórico entre o caso e esta análise permitiu um estudo mais 
detido e uma reflexão mais profunda que fundamentam a exposição das conclusões expostas. O debate, entretanto, é inesgotável.

\section{Fundamentos e considerações para uma crítica estética: análise de "A triste história de Eredegalda"}

Inicialmente é necessário firmar os fundamentos teórico-filosóficos sobre os quais se assentam as análises expostas a seguir: uma compreensão da estética de base marxista sistematizada e divulgada, principalmente a partir do século XX, por György Lukács e Mikhail Lifshitz, após estudos dos manuscritos de Marx arquivados no Instituto Marx-Engels-Lenin de Moscou, em meados de 1930. A crítica desenvolvida aqui se apoia em Lukács, fundamentalmente em sua Estética, escrita em meados de 1960, que não é um autor de tradicional influência no campo da teoria e crítica literária, assim como são poucos os teóricos contemporâneos que, nesse campo, se advogam marxistas.

O marxismo, porém, influenciou diversas áreas do conhecimento. Não seria diferente com a arte e a literatura: colaborou ou influenciou, em diferentes medidas, na formação de muitas personalidades, como Raymond Williams, Noam Chomsky, Terry Eagleton, Ernest Ficher, Mikhail Bakhtin, Adolfo Sánchez Vásquez, Fredric Jameson, Adorno, dentre outros; no Brasil, Carlos Nelson Coutinho, Antonio Candido, Nelson Werneck Sodré, Celso Frederico, Ferreira Gullar, Roberto Schwarz, Jorge Amado, Carlos Drummond de Andrade, Graciliano Ramos, dentre outros. Diante disso, é possível reivindicar a legitimidade de análises marxistas no campo da arte, da literatura e da cultura em geral. Este estudo especificamente é de tradição lukacsiana.

Para os fins de análise do caso do romance "A triste história de Eredegalda", é preciso esclarecer os conceitos lukacsianos fundamentais para a compreensão da exposição, são eles: a cotidianidade como solo em que nasce a necessidade da arte, a arte como reflexo de uma realidade objetiva e exterior ao ser humano, a catarse estética como síntese de um conhecimento acerca da vida humana proporcionado pela arte e o realismo como forma elevada de arte. O realismo na arte se conecta com o método marxista, na medida em que a realidade objetiva existe antes de quaisquer reflexos sobre ela, sendo mais complexa que o conhecimento que se possa ter sobre ela (XEREX; COSTA; SANTOS, 2017). 
De acordo com Lukács (1982a), todas as objetivações humanas ${ }^{3}$ partem do solo comum da cotidianidade e a ela retornam. No cotidiano, as decisões humanas são fundadas em motivos de natureza instantânea, rígida e fugaz. Há nela uma vinculação imediata entre teoria e prática, pois, na vida cotidiana, é necessário que o entorno do ser humano tenha para ele uma finalidade prática. Ele reage aos objetos de sua cercania de um modo espontaneamente prático, não há uma completa separação entre o agir e o pensar. O cotidiano é também heterogêneo.

A trabalhadora, exausta de uma longa caminhada, depois de um dia exaustivo de trabalho, ao encontrar assento vazio no ônibus, senta. Por mais capacitada que seja para filosofar acerca da cadeira, do ônibus, das condições do transporte público brasileiro, sobre a lei da inércia, sobre o designer da cadeira, etc., ela não o faz, pois a cadeira possibilita o sentar, uma ação que responde a uma necessidade imediata no cotidiano dessa mulher. Observe-se que a mulher, nesse caso simbólico, possui, na sua consciência, no momento do sentar, reflexos que possibilitam esta ação: ela sabe a função do objeto cadeira, ela sabe se deslocar num ônibus em movimento, sabe que precisa segurar em caso de freada, etc.

O homem e a mulher, imersos no cotidiano, respondem a necessidades práticas imediatas. Dessa forma, Lukács (1982a) denomina homem inteiro o que está imerso na cotidianidade, pois este orienta a sua realidade com toda a superfície de sua existência. Quando esse homem inteiro se afasta da cotidianidade e se debruça sobre uma objetivação artística, cedendo a ela a inteireza de seu ser, Lukács (1982a) o chama de homem inteiramente.

No exemplo acima da trabalhadora, surgiu uma categoria e há a necessidade de explicá-la, segundo Lukács (1982a): o reflexo. O homem vivencia o mundo por meio das experiências e o organiza na consciência por meio dos reflexos, das imagens do mundo exterior. A construção desse reflexo na consciência é mediada pela inseparabilidade entre pensamento e linguagem e sua elaboração significa uma ampliação do domínio da realidade pelo homem. Aqui vale a ressalva: o mundo refletido é exterior e independente da consciência humana, entretanto, mediante o movimento do reflexo, da elaboração de

3 Objetivação é a efetivação de uma prévia ideação de um sujeito. Pode ter uma materialidade física como uma cadeira ou uma objetividade social como o valor ou a linguagem.

Educação \& Formação, Fortaleza, v. 5, n. 3, e2996, set./dez. 2020 
conceitos, o mundo externo vai perdendo a imediatez originária, consequentemente o ser humano vai podendo atuar nesse mundo de modo mais consciente.

Lukács (1982a) desenvolve conceitos sobre três formas de reflexo da realidade: o reflexo da vida cotidiana como ponto médio e os reflexos da ciência e da arte nos extremos. Não cabe nos objetivos deste texto desenvolver a teoria do reflexo lukacsiana. É necessário, entretanto, aduzir às características do reflexo artístico da realidade: é antropomorfizador, cria um mundo próprio homogêneo que suspende o ser humano da heterogeneidade da vida cotidiana; eleva o indivíduo ao típico.

O realismo luckacsiano defende, com base nessas e em outras categorias, o realismo literário como posição estética e compromisso do artista. Lukács (2010) afirma que a literatura deve relacionar fatos singulares a situações gerais, assim os acontecimentos narrados ressaltariam seu caráter exemplar. Para ser verossímil e respeitar a objetividade do real, necessita figurar uma totalidade. Nessa totalidade, os personagens são típicos, ou seja, vivem em suas vidas singulares problemas gerais - é a figuração de formas sociais -, ligando o individual ao universal.

Triunfaria, assim, o realismo. "[...] um triunfo da representação realista, do reflexo literariamente exato e profundo da realidade, sobre os preconceitos individuais e classistas do escritor" (LUKÁCS, 2010, p. 75). O significado da palavra "realismo" pode levar a diversas interpretações. Consoante Jakobson (2013, p. 110-111), essa palavra tem conteúdo vago. Pode significar a obra que o autor em questão projetou verossímil, pode significar a obra cujo julgamento de outrem a tome como verossímil, pode ser "[...] a soma dos traços característicos de uma escola tradicional do século XIX". Jakobson (2013) adverte para as possibilidades de ambiguidade dessas definições. Mesmo correndo esse risco, aqui se define realismo, nos termos de Lukács, como compromisso em refletir a totalidade da realidade de maneira mais aproximada possível.

É possível, após essa breve explanação, ingressar na exposição do caráter pedagógico da obra de arte. Antes, uma advertência: não se está afirmando que arte e educação são idênticas como complexos sociais, mas que há na arte um caráter, uma dimensão pedagógica, conforme Lukács (1982a). Vale ressaltar que "[...] a prática educativa escolar é mediadora entre a esfera da vida cotidiana e as esferas da vida não cotidianas no processo de formação do indivíduo" (MORORÓ, 2017, p. 41). 
O mundo próprio de cada obra arte, aludido acima, é um mundo particular que possui leis próprias e que não se aplicam a outras. Esse mundo não contradiz o caráter de reflexo da realidade objetiva, porque, por um lado, ela cria um mundo próprio orgânico em si mesmo; por outro lado, ela age num sentido análogo (LUKÁCS, 1978). Como se figuram destinos humanos, o leitor se identifica com a universalidade representada no típico, relacionando-se com a obra como se ela não fosse um reflexo. A função da arte é a de desfetichizar a realidade, segundo Lukács (1982b).

A arte exerce o papel de autoconsciência do desenvolvimento humano, de percepção de si mesmo do sujeito, do ser humano como diferenciado da natureza orgânica, visto que, segundo o filósofo magiar, nela há uma tendência para a imanência terrena, ou seja, no reflexo estético, o homem está sempre presente como determinante.

A eficácia pedagógico-social da arte, consequentemente da literatura, tem como momento decisivo a elevação do indivíduo da mera particularidade do sujeito à particularidade. O leitor experimenta novas vivências, muitas vezes, distantes de seu cotidiano, que, ao mesmo tempo que Ihe são estranhas como indivíduo singular, são reconhecidas por ele como humanas, assim o indivíduo é enriquecido na sua individualidade. Se nenhum indivíduo é tabula rasa, a eficácia da obra também não é independente do receptor, mas uma síntese de determinações objetivas da obra e subjetivas do leitor, por isso não pode ser entendida como mecânica. "Le acuden nuevos contenidos que aumentan su tesoro vivencial" (LUKÁCS, 1982b, p. 496).

A catarse, para Lukács (1982b), vai além da tragédia. Para ele, a catarse, como todas as categorias humanas, tem origem na vida cotidiana; na arte, ela é um reflexo. A catarse produz no homem uma sacudida na subjetividade, em seu pathos ${ }^{4}$, cobre novos conteúdos, novas direções, ou seja, através da catarse, possibilitada na relação com uma obra de arte, o ser humano aprende mais sobre si mesmo. Os conteúdos não são da mesma natureza daqueles obtidos pela ciência, são conteúdos antropomórficos, com um significado para si, para dentro dos seres.

Assentadas as bases segundo as quais se executou a análise do romance "A triste história de Eredegalda", expõem-se abaixo os resultados deste estudo. Não se pretendeu esgotar o debate, selar o ponto final, nem condenar ou defender o texto, mas

4 Lukács (2011) não o entende apenas como paixão, mas uma potência que se exterioriza na paixão, uma potência da alma, um conteúdo essencial da racionalidade.

Educação \& Formação, Fortaleza, v. 5, n. 3, e2996, set./dez. 2020 
discutir, à luz de um referencial teórico explícito, as determinações do romance e a função pedagógica que ele, por sua natureza imanente, pode suscitar em sala de aula. A questão central aqui é: de que forma "A triste história de Eredegalda" contribui para a formação das crianças entre 6 e 8 anos de escolas públicas brasileiras?

O destaque acima não é gratuito: "crianças entre 6 e 8 anos de escolas públicas brasileiras" aponta para o contexto em que essa obra deveria ser trabalhada, indica um norte para análise, marca a classe, a realidade e as necessidades dessas crianças, salienta que nenhuma obra literária é lida no vácuo, que nenhum receptor é tabula rasa.

\subsection{Considerações sobre as especificidades das dimensões estética e pedagógica: um ensaio sobre "A triste história de Eredegalda"}

A negação do romance de Brant, como se pôde ver, deu-se pela via da crítica moral; ao passo que a defesa feita tanto pelo Ceale - FaE/UFMG quanto pelo próprio autor visam defender a liberdade artística, o direito indiscutível de um autor tematizar aquilo que deseja. A crítica esboçada nestas linhas objetiva superar ${ }^{5}$ esses dois pontos de vista, tendo em foco o caráter pedagógico de "A triste história de Eredegalda", isto é, sua utilização em sala de aula como instrumento para o ensino.

A práxis educativa possui uma especificidade básica, reproduzir criativamente, por uma série de mediações, em cada indivíduo singular um conjunto de habilidades, conhecimentos, valores, necessidades e predisposições, previamente postas por cada sociedade concreta. Conforme Saviani (2008), a educação escolar é a forma superior criada pelos seres humanos de produção nos indivíduos dos atributos que definem os níveis mais elevados que o gênero humano alcançou historicamente. Então, nessa perspectiva, o ensino escolar possui a função de fazer com que os educandos se apropriem dos conteúdos científicos, artísticos e filosóficos, como parte do processo, que em uma sociedade capitalista é contraditório, de formação de individualidades mais enriquecidas.

Assim, de acordo com Duarte (2016), os conhecimentos científicos, artísticos e filosóficos carregam atividade humana condensada, sintetizada, como vida latente. No

5 No marxismo, superação dialética é simultaneamente a negação de uma determinada realidade, a conservação de algo de essencial que existe nessa realidade negada e a elevação dela a um nível superior.

Educação \& Formação, Fortaleza, v. 5, n. 3, e2996, set./dez. 2020

DOI: https://doi.org/10.25053/redufor.v5i15set/dez.2996

https://revistas.uece.br/index.php/redufor/index 
processo pedagógico, mediado pela práxis docente, a atividade contida nesses conhecimentos transforma-se em atividade subjetiva dos educandos e se incorpora à sua "segunda natureza": numa dialética entre a objetivação histórica da cultura e sua apropriação pelos indivíduos. Nesse sentido, o conteúdo de literatura na escola está subordinado a esse processo de desenvolvimento de individualidades enriquecidas pela apropriação do melhor que foi produzido pela humanidade.

O uso da obra literária em sala de aula não possui a mesma função que o acesso a ela fora desse espaço, haja vista que, ao ser utilizada pelo professor, está subsumida à esfera pedagógica. Há entre a obra e seus constituintes - autor, forma e conteúdo - uma mediação: a do professor. Ressalte-se que o receptor é, além disso, um educando. Obra e educando estão, portanto, numa relação de aprendizagem. O que era mais direto, com mediações circunstanciais, obra - receptor, passa a ser mediado de maneira premeditada: obra - professor - receptor/educando.

A mediação do professor não se dá de forma acidental, mas sua aula é programada para que as atividades que enseja, mediante os instrumentos que resolve utilizar, conduzam o aluno à apropriação de um conteúdo. Desse modo, cabe perguntar: qual o conteúdo pedagógico de "A triste história de Eredegalda"? Quais elementos da leitura serão apropriados pelo estudante? Qual o conhecimento que essa obra gera no educando? Considera-se aqui que são as respostas para essas perguntas que viabilizam ou não uma obra como pedagogicamente adequada ao desenvolvimento de determinado conteúdo para sua finalidade: a apropriação por parte do discente.

Entenda-se que se trata não mais da liberdade abstrata do mundo: um autor escreve o que Ihe convém, um leitor lê o que lhe interessa, mas o professor utiliza o que Ihe é adequado ao ensino, melhor, aos seus objetivos de ensino. Desse modo, a liberdade da obra no ambiente escolar está subordinada à lógica imanente do processo educativo. Outros elementos pesam na escolha do professor: idade dos alunos, conhecimento acerca do papel da arte, da literatura e das obras escolhidas, nível de leitura dos aprendizes, obras disponíveis, por exemplo. Assim, mesmo em aulas de leitura livre, há uma seleção prévia daquelas que melhor se adéquam a esses fatores.

O resultado da leitura em sala de aula e na vida não é o mesmo. A catarse estética não pode ser garantida, pois o que a medeia é uma série de motivos subjetivos e objetivos na relação obra e leitor. Na sala de aula, o professor pode indicar, construir 
os elementos necessários ao entendimento de uma obra, mas esse conhecimento não se iguala em conteúdo e forma à catarse estética. Assim, o ensino de literatura tem uma função mais ampla. Para destacá-la, as palavras de Perrone-Moisés (2016, p. 80-81) são singulares:

\begin{abstract}
Sintetizando o que foi dito pelos melhores teóricos, responderíamos à pergunta 'Por que ensinar estudar Literatura?' com os seguintes argumentos: porque ensinar literatura é ensinar a ler e, nas sociedades letradas, sem leitura não há cultura; porque a capacidade de leitura não é inata, mas adquirida; porque os textos literários podem incluir todos os outros tipos de textos que o aluno deve conhecer, para ser um cidadão apto a viver em sociedade; porque os textos literários são aqueles em que a linguagem atinge seu mais alto grau de precisão e sua maior potência de significação; porque a significação, no texto literário, não se reduz ao significado (como acontece nos textos científicos, jornalísticos, técnicos), mas opera a interação de vários níveis semânticos e resulta numa possibilidade teoricamente infinita de interpretações; porque a literatura é um instrumento de conhecimento do outro e de autoconhecimento; porque a literatura de ficção, ao mesmo tempo que ilumina a realidade, mostra que outras realidades são possíveis, libertando o leitor de seu contexto estreito e desenvolvendo nele a capacidade de imaginar, que é uma necessidade humana e pode inspirar transformações históricas; porque a poesia capta níveis de percepção e de fruição da realidade que outros tipos de texto não alcançam.
\end{abstract}

A autora ainda afirma: "Se acreditamos nas virtudes específicas da literatura acima arroladas, devemos ensiná-las a partir das obras que as possuem" (PERRONE-MOISÉS, 2016, p. 81). Questiona-se: a obra "A triste história de Eredegalda" possui essas virtudes? Se a resposta for sim, ela é adequada ao uso pedagógico, apesar de tematizar um assunto demasiado espinhoso, como o incesto. Se a resposta a essa pergunta for não, a obra é dispensável do ponto de vista pedagógico e seria um desgaste inócuo seu uso em sala de aula.

Avaliou-se, então, que o romance analisado não possui essas virtudes. Não é a análise literária que justifica este artigo, mas a possibilidade que a polêmica enseja: 0 que cabe à educação no ensino da arte e consequentemente da literatura. A obra "A triste história de Eredegalda" é uma resposta alienada a uma situação alienada. A situação a que se refere a afirmação anterior diz respeito à escola pública brasileira na atualidade: instituições, salvo raras exceções, precárias e esvaziadas da função de transmitir o que de mais elevado se produziu na história humana, em que a atividade docente, também esvaziada, é exercida por pessoas em condições de trabalho extenuantes, mal remuneradas, sem oportunidades de ampliar sua formação e preparação nas diversas áreas, já que são polivalentes, etc. 
Se a tematização do incesto visava elevar os educandos de seu cotidiano para, por exemplo, aprender que o outro não possui direito ao corpo da criança, a denunciar quaisquer tentativas de abuso, já que $40 \%$ das crianças que sofreram abuso sexual entre 2015 e 2016 eram crianças da faixa etária de 0 a 11 anos, segundo o MEC (BRASIL, 2017), ao contrário, a narrativa da vida de Eredegalda, pela própria natureza do gênero, é abstrata, ou seja, carente de determinações que permitam ao leitor, em especial à criança, apropriar-se do conteúdo desenvolvido para que sua vivência seja enriquecida. A trova popular desenvolve uma narrativa aberta; o leitor preenche o que falta. No caso da criança em fase de alfabetização, é pouco provável que ela tenha vivências e uma compreensão suficiente dessas vivências para fazê-lo sem que a narrativa se choque com suas próprias experiências como realidade, e não como reflexo. Uma criança que sofra ou tenha sofrido abuso sexual do próprio pai pode mais se ferir do que superar a vivência que o romance figura.

Além do que foi dito antes, o Ceale - Fae/UFMG, ao argumentar a estrutura linguística do texto, seus verbos no passado, a negação veemente de Eredegalda, etc., omite a estrofe em que a protagonista cede ao desejo do pai e lhe concede a mão. Após avistar o pai, novamente implora um copo d'água:

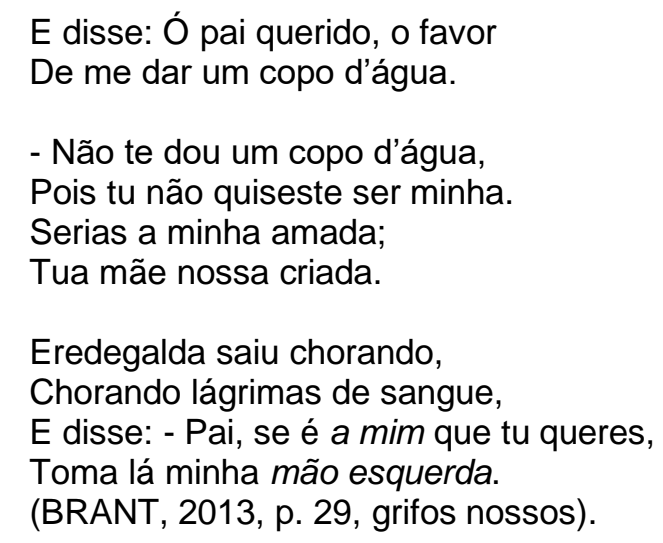

Conforme se pode ver nos destaques acima, Eredegalda tinha consciência da entrega de si mesma - do corpo aos caprichos do pai - e de que essa entrega resultaria em casamento. O reconto não apresenta a idade de Eredegalda para dar concretude aos conhecimentos e ações da personagem, assim a criança terá mais facilidade de identificar-se com a protagonista, inclusive pelo fato de as personagens do romance serem comuns nos contos maravilhosos, bem como o cenário apresentado: rei, rainha, 
princesa, torre. Provavelmente a criança recorre a memórias desse tipo de gênero, esperando um final feliz, comum nos contos maravilhosos e inexistente em "A triste história de Eredegalda", que culmina numa tragédia cuja salvação da personagem é a morte e a oportunidade de uma vida transcendente - não se discutirá aqui esta questão.

Por esses últimos elementos, de natureza mais estética do que pedagógica, compreende-se que a obra não possui efeito desfetichizador. Não possui elementos emancipatórios, no sentido de Lukács, pois figura um mundo alienado e não permite uma compreensão elevada desse mundo, colocando o leitor numa situação sem saída. O mundo próprio dessa obra é carente de determinações.

Mediante o que foi dito até aqui, vale destacar que o uso das obras literárias em sala de aula não é independente do papel da educação, dessa maneira a forma estética da obra de arte pode inviabilizar o processo pedagógico, bem como o processo pedagógico pode inviabilizar a apropriação estética da obra de arte. É relevante pensar sobre o papel da formação de professores para a educação infantil, pois essa etapa de ensino exige que o docente domine os conteúdos escolares que aplica (FONSECA; COLARES; COSTA, 2019). O caso de obra "A triste história de Eredegalda" é um exemplo disso.

\section{Considerações finais}

Inicialmente vale destacar que não se contesta a competência do Ceale FaE/UFMG na análise e seleção dos livros. Compreende-se aqui a defesa feita pelo Centro na tentativa de manter a obra nas escolas, o questionamento diz respeito à possibilidade de "A triste história de Eredegalda" exercer uma função pedagógica, bem como à possibilidade de a obra possuir um caráter educativo. Nesse sentido, essas considerações finais destacarão três momentos referentes a este artigo.

Primeiro: o centro da argumentação não é sobre a liberdade literária nem acerca do recurso à censura, baseado numa visão moralista e superficial. A liberdade literária, apesar de relativa, é inquestionável, ou seja, ela é relativa porque os autores tematizam aquilo que os interessa, mas eles o fazem nas condições e necessidades de um tempo histórico e de um contexto situado. O que se quer dizer é que o direito de Brant tratar 
sobre o incesto como conteúdo e desenvolvê-lo segundo a forma artística que escolheu está posto.

Segundo: vale destacar que o processo ocorreu em tempos históricos diferentes. A aprovação deu-se no ciclo de governos de frente popular ${ }^{6}$ do Partido dos Trabalhadores (PT) e representou avanços contraditórios nas políticas públicas educacionais; enquanto a censura e recolhimento do texto situam-se no período pós-golpe de Estado contra o governo eleito de Dilma Rousseff, período de avanço de ideias conservadoras e reacionárias, como o Movimento Escola sem Partido e a fabricação da chamada "ideologia de gênero".

Terceiro: a questão nuclear é que a obra de arte na sala de aula se subordina ao processo imanente da educação. Retomando a epígrafe deste texto, a literatura não se faz para ensinar, mas a reflexão sobre a literatura ensina. Assim, a obra de arte, no mundo, possuindo um caráter pedagógico, transforma o homem, modifica-o, ensina-o; em sala de aula, a mediação do professor deve educar os sentidos estéticos dos alunos para que eles estejam preparados para vivências estéticas de qualidade. Mesmo a literatura infantil deve ter qualidade, deve ter forma e conteúdo para essa aprendizagem: não é o caso de "A triste história de Eredegalda".

Vale destacar que se considera a retirada da obra das escolas como um equívoco, tendo em vista que se configurou como um ato de censura baseado em análises moralistas superficiais. Ao mesmo tempo, seria preciso uma preparação mais substancial para que os professores pudessem desenvolver um trabalho de qualidade no uso dessa obra, já que a formação para o uso do material do Pnaic é ainda deficitária, bem como as contundentes críticas à metodologia de alfabetização que a subjaz.

A tentativa de superação deste debate parece ter sido alcançada, já que se puseram as bases para uma análise mais além das posições correntes e com um fundamento teórico claro acerca das obras de arte. Tal análise permite a afirmação de que as obras escolhidas para sala de aula devem ser obras de qualidade, produzidas

6 Os governos frente-populistas surgem como uma vitória eleitoral ou revolucionária das massas e significam uma derrota equivalente da burguesia e de seus partidos mais representativos. Principais características: 1) o governo frente-populista coincide com uma etapa superior da luta de classes; 2) é um tipo diferente de governo burguês; 3) tem um conteúdo contrário à revolução socialista; 4) está apoiado nas organizações operárias conciliadoras ou com direções reformistas; 5) não tem nenhuma incompatibilidade com o regime capitalista; 6) sua atividade desmoraliza e desmobiliza os trabalhadores, levando-os a maiores sofrimentos ou a derrotas históricas; 7) é um produto histórico da crise de direção revolucionária.

Educação \& Formação, Fortaleza, v. 5, n. 3, e2996, set./dez. 2020

DOI: https://doi.org/10.25053/redufor.v5i15set/dez.2996

https://revistas.uece.br/index.php/redufor/index 
como obras literárias mesmo, não encomendadas ou que respondam às necessidades do Pnaic. O ensino de literatura deve ser feito com obras que permitam tal nomenclatura para que as crianças tenham experiências pedagógicas que formem seus sentidos estéticos e permitam vivências estéticas no mundo fora da sala de aula.

Talvez valha dizer que o papel dos professores das diversas artes, inclusive da literatura, seja dar condições para que a arte exerça seu papel. Isso não pode ser aferido numericamente; muitas vezes, sequer presenciado.

\section{Referências}

ALBUQUERQUE, M. Autor de livro atribui polêmica à falta de capacitação de professores. Gazeta Online, Vitória, 2 jun. 2017b. Disponível em: https://www.gazetaonline.com.br/noticias/cidades/2017/06/autor-de-livro-atribui-polemicaa-falta-de-capacitacao-de-professores-1014062096.html. Acesso em: 20 abr. 2020.

ALBUQUERQUE, M. Livro infantil que sugere casamento entre pai e filha é retirado de escolas no ES. G1 Espírito Santo - TV Gazeta, Vitória, jun. 2017. Disponível em: https://g1.globo.com/espirito-santo/noticia/livro-infantil-que-sugere-casamento-entre-paie-filha-e-retirado-de-escolas-no-es.ghtml. Acesso em: 29 jan. 2018.

BRANT, J. M. Enquanto o sono não vem. Rio de Janeiro: JPA, 2013.

BRASIL. Portal Brasil, com informações da Secretaria de Direitos Humanos. 2017. Disponível em: http://www.brasil.gov.br/cidadania-e-justica/2017/05/dia-nacional-contraabuso-sexual-de-criancas-e-jovens-e-celebrado-nesta-quinta-18. Acesso em: 20 abr. 2020.

CEALE - Centro de Alfabetização, Leitura e Escrita. Nota técnica sobre o livro "Enquanto o sono não vem". Pampulha: UFMG, 2017.

DUARTE, N. Os conteúdos escolares e a ressureição dos mortos: contribuição à teoria histórico-crítica do currículo. Campinas: Autores Associados, 2016.

FERREIRA, P. "Demonizar um conto é consequência de nossa crise moral", diz autor de livro recolhido pelo MEC. G1 O Globo, Rio de Janeiro, 8 jun. 2017. Disponível em: https://oglobo.globo.com/sociedade/educacao/demonizar-um-conto-consequencia-de-nossacrise-moral-diz-autor-de-livro-recolhido-pelo-mec-21453077. Acesso em: 20 fev. 2018.

FONSECA, A.; COLARES, A.; DA COSTA, S. Educação infantil: história, formação e desafios. Educação \& Formação, Fortaleza, v. 4, n. 12, p. 82-103, 2019. Disponível em: https://revistas.uece.br/index.php/redufor/article/view/1270/1305. Acesso em: 20 fev. 2020. 
JAKOBSON, R. Do realismo na arte. In: TODOROV, T. (Org.). Textos dos formalistas russos. São Paulo: Unesp, 2013. p. 109-122.

LUKÁCS, G. As bases ontológicas do pensamento e da atividade do homem. In: NOGUEIRA, M. A. et al. (Org.). Temas de Ciências Humanas. São Paulo: Ciências Humanas, 1978. p. 1-21.

LUKÁCS, G. Estética 1: la peculiaridad de lo estético. Barcelona: Grijaldo, 1982a. v. 1.

LUKÁCS, G. Estética 2: la peculiaridad de lo estético. Barcelona: Grijaldo, 1982b. v. 2.

LUKÁCS, G. Friedrich Engels, teórico e crítico da literatura. In: LUKÁCS, G. Marxismo e teoria da literatura. 2. ed. São Paulo: Expressão Popular, 2010. p. 51-103.

LUKÁCS, G. O romance como epopeia burguesa. In: LUKÁCS, G. Arte e sociedade: escritos estéticos 1932-1967. 2. ed. Rio de Janeiro: UFRJ, 2011. p. 193-243.

MEC - Ministério da Educação. Com base em parecer técnico, MEC recolhe das escolas o livro Enquanto o sono não vem. Assessoria de Comunicação Social. Brasília, DF, 8 jun. 2017. Disponível em: http://portal.mec.gov.br/component/content/article?id=50011:mecrecolhe-das-escolas-o-livro-enquanto-o-sono-nao-vem. Acesso em: 29 jan. 2018.

MORORÓ, L. A influência da formação continuada na prática docente. Educação \& Formação, Fortaleza, v. 2, n. 4, p. 36-51, 2017. Disponível em:

https://revistas.uece.br/index.php/redufor/article/view/122/105. Acesso em: 20 abr. 2020.

PERRONE-MOISÉS, L. O ensino da literatura. In: PERRONE-MOISÉS, L. Mutações da literatura no século XXI. São Paulo: Companhia das Letras, 2016. p. 70-82.

SAVIANI, D. Pedagogia histórico-crítica: primeiras aproximações. 10. ed. Campinas: Autores Associados, 2008.

XEREZ, A. S.; COSTA, F. J.; SANTOS, J. D. Educação profissional integrada ao nível médio no Ceará: reformas e contradições. Educação \& Formação, Fortaleza, v. 2, n. 4, p. 204-223, 2017. Disponível em:

https://revistas.uece.br/index.php/redufor/article/view/130/115. Acesso em: 20 abr. 2020.

\footnotetext{
Karla Raphaella Costa Pereira, Centro Universitário Uninassau (Uninassau), Departamento de Educação, Curso de Pedagogia

iDhttp://orcid.org/0000-0001-7507-4627

Doutora e mestra em Educação pela Universidade Estadual do Ceará (UECE), na linha Marxismo e Formação do Educador, e graduada em Letras-Português/Literaturas pela Universidade Federal do Ceará (UFC) e em Pedagogia pela UECE. Coordenadora do Grupo de Pesquisa Ontologia do Ser Social, História, Educação e Emancipação Humana (GPOSSHE) da UECE.

Contribuição de autoria: Administração do projeto, análise formal, conceituação, escrita da redação, investigação e metodologia.

Lattes: http://lattes.cnpq.br/6592056073051492

E-mail: karla_raphaella@hotmail.com
} 
Frederico Jorge Ferreira Costa, Universidade Estadual do Ceará (UECE), Faculdade de Educação de Itapipoca, Curso de Pedagogia

ii Dhttp://orcid.org/0000-0002-8357-4557

Pós-Doutor em Filosofia, doutor e mestre em Educação e graduado em Direito. Professor da Universidade Estadual do Ceará (UECE), do Programa de Pós-Graduação em Educação (PPGE). Coordenador do Grupo de Pesquisa Ontologia do Ser Social, História, Educação e Emancipação Humana (GPOSSHE) da UECE.

Contribuição de autoria: Escrita da revisão, edição e supervisão.

Lattes: http://lattes.cnpq.br/7944751664196175

E-mail: frederico.costa@uece.br

Ana Paula Sancho Diogo, Prefeitura Municipal de Fortaleza, Secretaria Municipal de Educação iii Dhttp://orcid.org/0000-0001-9654-363X

Mestra em Educação pela Universidade Estadual do Ceará (UECE), na linha Marxismo e Formação do Educador, especialista em Linguística Aplicada em Língua Portuguesa pela Faculdade Sete de Setembro (FA7) e em Docência nas Séries Iniciais do Ensino Fundamental I pela UECE e graduada em Pedagogia pela Universidade Federal do Ceará (UFC). Professora da rede municipal de ensino de Fortaleza.

Contribuição de autoria: Escrita da redação e elaboração da análise formal.

Lattes: http://lattes.cnpq.br/3221880371802043

E-mail: anapaulasancho@yahoo.com.br

Editora responsável: Lia Machado Fiuza Fialho

Pareceristas ad hoc: Karla Silva e Cristine Brandenburg

\section{Como citar este artigo (ABNT):}

PEREIRA, Karla Raphaella Costa; COSTA, Frederico Jorge Ferreira; SANCHO DIOGO, Ana Paula. Contraposições entre estética e ensino da arte: o caso de "A triste história de Eredegalda". Educ. Form., Fortaleza, v. 5, n. 3, p. 1-22, 2020. Disponível em: https://revistas.uece.br/index.php/redufor/article/view/2996.

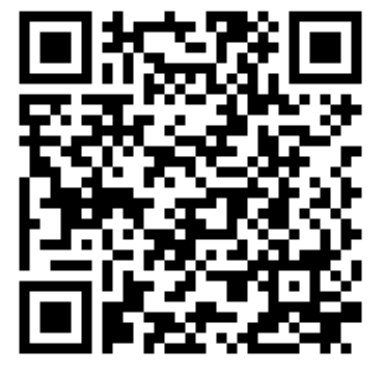

Recebido em 14 de abril de 2020.

Aceito em 5 de maio de 2020.

Publicado em 15 de abril de 2020.

Educação \& Formação, Fortaleza, v. 5, n. 3, e2996, set./dez. 2020

DOI: https://doi.org/10.25053/redufor.v5i15set/dez.2996

https://revistas.uece.br/index.php/redufor/index 